\title{
THE ORIGIN OF MALTREATMENT: AN EXPLORATORY STUDY ON THE INTERGENERATIONAL TRANSMISSION OF CHILD ABUSE TYPOLOGIES
}

\author{
Raquel V. Oliveira ${ }^{*}$, JoÃo Maroco** and LÚCia G. Pais**
}

*Master's Degree in Clinical Psychology and Licentiate Degree in Applied Psychology.

Technical Assistant at the Research Unit in Psychology and Health (UIPES).

E-Mail: roliveira@ispa.pt / raquel.I.v.oliveira@gmail.com

${ }^{* *} \mathrm{PhD}$ in Plant Physiology and Biochemistry. Member of the Research Unit in Psychology and Health (UIPES), and Associate Professor of Statistics in ISPA-IU. E-Mail: jpmaroco@ispa.pt ${ }^{* * *} \mathrm{PhD}$ in Psychology (Criminal and Forensic Psychology), Post-Graduate Course in Criminology, and Licentiate Degree in Clinical Psychology. Professor of Psychology and Scientific Coordinator of the Major Events Laboratory at Higher Institute of Police Sciences and Internal Security, Lisbon, Portugal. Member of the Field Study Group and the Researchers Group of the GODIAC Research Project - ISEC. Professor of Forensic Psychology and Testimony at the Higher Sciences Egas Moniz. E-Mail: luciapais@netcabo.pt

Instituto Universitário (ISPA), Rua Jardim do Tabaco, 34, 1149-041, Lisbon, Portugal.

\section{RESUMEN}

El objetivo del trabajo que se informa fue determinar si, en casos de transmisión inter-generacional de maltrato, se verificaba transmisión de tipologías de abuso y establecer el contexto del abuso. Se desarrolló un estudio exploratorio con 10 agresores de niños, quienes habían sido víctimas de abuso. Para la recolección de datos se utilizaron una entrevista semi-estructurada y un cuestionario socio-demográfico. Se realizó un análisis del contenido para estudiar los datos textuales, el test de Fisher para determinar la posible dependencia entre los tipos de abuso sufridos y practicados y análisis del componente principal para explorar asociaciones entre categorías. Se verificó la transmisión del abuso físico en siete casos, en dos casos de abuso psicológico y en dos de negligencia. No se encontró asociación estadísticamente significativa entre las tipologías de abuso sufrido y practicado. Las categorías Entorno Familiar (218 unidades de re- gistro -u.r- unidad de codificación básica) y Relaciones Intrafamiliares (151u.r.) presentaron el mayor número de u.r., y las categorías Abuso Sexual (1u.r.) y Agresor como Figura de Identificación Reconocida (4u.r.), el más bajo. El contexto del abuso se explica mejor mediante un modelo bidimensional: Maltrato e Interacciones Sociales y Contexto del Abuso, Sentimientos y Percepciones. Se encontraron fuertes asociaciones entre Abuso Psicológico y Físico, Relaciones Interpersonales, Inclinación al Abuso y Hábitos Tóxicos, y entre ser la única víctima de agresiones, viendo al otro como figura de identificación y sentimientos negativos hacia el agresor. La transmisión de las tipologías de abuso no fue significativa, pero se encontraron asociaciones entre aspectos contextuales y son discutidos junto con sus limitaciones e implicaciones.

Palabras clave: Transmisión inter-generacional del abuso; Maltrato; Agresores; Niños; Tipos de maltrato. 


\section{ABSTRACT}

The way child maltreatment has been seen and dealt with has changed over time. Nowadays, it is a phenomenon of great importance and social recognition, being the target of many studies, and having led to the creation and implementation of several protection measures. The intergenerational transmission of maltreatment is one of the main causes for current child abuse and neglect. In this way, our objective was to assess whether a transmission of abuse typologies occurred, in the cases where an intergenerational transmission of maltreatment is observed. Thus, we developed an exploratory study using a convenience sample of 10 child aggressors, who had been victims of abuse during their own childhood, from the district. All participants fulfilled the inclusion criteria and had similar socio-economic background. The participants gave their informed consent to participate in this study.

For data collection we used a semi-structured interview, developed specifically for this study, and a socio-demographic questionnaire that enabled a characterization of the sample. All the interviews were recorded and transcribed verbatim. The data produced was then analyzed using as used content analysis, to study the textual data collected with the interviews, and principal components analysis. Fisher's test was used to determine the association between suffered and inflicted types of abuse $(p<.005$ was considered significant).

Based on our data analysis we observed that in seven cases there was an intergenerational transmission of Physical Abuse, in two cases of Psychological Abuse and in another two cases of Neglect. In four cases different types of abuse, than those suffered, arose. In five cases, several types of abuse were inflicted concomitantly. However, there was no statistically significant relation between the types of abuse suffered and those inflicted. Furthermore, 813 recording units (r.u. - which are basic codification units) were obtained in the content analysis, throughout the seven pre-categories (21 categories, 10 subcategories). The content analysis' categories Family Environment and Intra-family Relationships, were the ones with the highest number of r.u., and also the most disparate, when compared with the remaining categories (Family Environ- ment $=218$ r.u., Intra-family Relationships $=151$ r.u.); being followed by Physical Abuse (87 r.u.) and Feelings towards the Perpetrator (58 r.u.). In opposition, the categories with the lowest number of r.u. were Sexual Abuse (1 r.u.) and Aggressor as Recognized Identification Figure (4 r.u.).

Moreover, we also found differences between the participants who inflict Physical Abuse and those who are negligent, as Physical Abuse is transmitted in most cases while negligence is not. Differences were also found in the quality of the family environment, outside-family relationships and self-recognition as aggressors. A relation between excusing / exonerating the aggressor and feeling self-guilt for the abuse was found. Also, a relation between naming the aggressor as the identification figure and self-recognition as an aggressor was found in this sample.

A principal component analysis was performed and the results evidenced that the context where the abuse occurs is better explained by a twodimension model, being the dimensions Maltreatment and Social Interactions and Abuse Context, Feelings and Perceptions. Strong associations were found between Psychological and Physical Abuse, Interpersonal Relationships, Feelings towards Abuse, and Toxic Habits / Consumptions, or no apparent reason as causes for abuse; and between being the only victim of aggressions, perceiving other (not the aggressor) as an identification figure and negative feelings towards the aggressor.

The transmission of abuse typologies was not statistically significant in this sample; however associations between contextual aspects were found and are discussed along with the limitations and implications of this study. Furthermore, we believe this information could be applied in the development of primary prevention and intervention programs.

Key words: Maltreatment; Aggressors; Children; Intergenerational; Maltreatment types.

\section{INTRODUCTION}

There has been much debate on the definition of child maltreatment, and on what con- 
stitutes each type of maltreatment, how to set thresholds or cut-off points, and how it can be limited by national laws (Azevedo \& Maia, 2006; Grilo, 2004; Kelly \& Pringle, 2009; Oliveira-Formosinho \& Araújo, 2002; Sneddon, Iwaniec, \& Stewart 2010; United Nations, 2006). According to international guidelines, maltreatment can be considered as any non-accidental action, or omission, that jeopardizes the satisfaction of the children's physical or emotional needs, or the full implementation of their rights and freedom (Azevedo \& Maia, 2006; Oliveira-Formosinho \& Araújo, 2002; Palacios, Jiménez, Oliva, \& Saldaña, 1998; Palacios, Moreno, \& Jiménez, 1995).

This definition covers a broad spectrum of maltreatment. However, the most reported types of maltreatment are: Physical Abuse, Psychological Abuse, Neglect and Sexual Abuse.

Physical abuse can be defined as intentional acts of commission by a caregiver that cause actual physical harm, or have the potential for harm, which may leave or not visible lesion (Azevedo \& Maia, 2006; Grilo, 2004; Palacios et al., 1995, 1998; Runyan, Wattam, Ikeda, Hassan, \& Ramiro, 2002; Sneddon et al., 2010)

Psychological abuse is the failure to provide an appropriate and supportive environment for the child, and includes acts that have an adverse effect on his / her emotional health and development, such as: denigration, ridicule, threats and intimidation, discrimination, rejection, blocking the child's attempts to interact and other nonphysical forms of hostile treatment (Grilo, 2004; Oliveira-Formosinho \& Araújo, 2002; Runyan et al., 2002; Sneddon et al., 2010; United Nations, 2006).

Neglect refers to the failure of a caregiver to provide for the child's basic physical or emotional needs (when the adult is in a position to do so), thus, to acts of omission, and non-protection of the child (Erickson \& Egeland, 2002; Grilo, 2004; Runyan et al., 2002; Sneddon et al., 2010). Neglect may be divided in physical and emotional neglect. Physical neglect is characterized by the nonsatisfaction of the child's basic physical needs such as feeding, health care, adequate cloth- ing, hygiene, schooling, etc. (Chadwick, 1999; Morais, 2001; Oliveira-Formosinho \& Araújo, 2002; Sneddon et al., 2010; United Nations, 2006). Emotional neglect has to do with the lack or absence of response by the parents to the child's communication and interaction attempts (Morais, 2001; Oliveira-Formosinho \& Araújo, 2002; Sneddon et al., 2010; United Nations, 2006).

Sexual abuse is defined as those acts where a child is used by a caregiver / adult for sexual gratification of the caregiver / adult or of another person (Grilo, 2004; Oliveira-Formosinho \& Araújo, 2002; Runyan et al., 2002; Sneddon et al., 2010).

In 2006, a report published by the United Nations presented statistics on child abuse worldwide. The data reported showed that in 2002 about 53,000 children died as a result of maltreatment; a total of 150 million girls and 73 million boys have been victims of sexual abuse; between 133 and 275 million children were victims of domestic violence (United Nations, 2006).

Moreover, the World Health Organization published in 2002 the first World Report on Violence and Health, where data from the WorldSAFE study was presented. This report assessed the incidence of abuse in several countries, being that the most common type of maltreatment is physical abuse followed by psychological abuse. For example, concerning moderate physical abuse, such as hitting, presented a prevalence of $47 \%$ in the United States, $75 \%$ in the Philippines, 58\% in India, and $51 \%$ in Chile. Psychological abuse, such as screaming / yelling at the child presented rates of $85 \%$ in the United States, $82 \%$ in the Philippines, $70 \%$ in India, and $84 \%$ in Chile (Runyan et al., 2002).

Regarding Portuguese data, between 2000 and 2009 a total of 5917 children and teenagers resorted to Portuguese Association for Victim Support (Statistics Unit of APAV, 2010). In $2010,54.57 \%$ of all reported crimes were related to child maltreatment (Statistics Unit of APAV, 2011). In most cases the victims were female, with ages between 11 and 17 years, and were target of physical or psychological abuse (Statistics Unit of APAV, 2010). 
There are several hypothesis and theories concerning the causes of maltreatment, some examples are: the child's characteristics (e.g. age, behavior, physical aspect, illness) (Azevedo \& Maia, 2006; Finkelhor \& DziubaLeatherman, 1994; Sherrod, O'Connor, Vietze, \& Altemeier, 1984; Sidebotham \& Heron, 2006); perpetrator's psychological / psychiatric issues (e.g. personality disorders, alco- holism, drug addiction) (Azevedo \& Maia, 2006; Sidebotham \& Heron, 2006); stressful social and / or family environment (e.g. lack of social support, conflictual family / couple relationships, economic pressure, job pressure, isolation, social / cultural acceptance of violence) (Azevedo \& Maia, 2006; Browne, 1998; Eckert, Ribeiro, Silva, \& Sousa, 2007; Holden \& Ritchie, 1991; Margolin \& John, 1997; Rogosh, Cicchetti, Shields, \& Toth, 1995; Trickett, Aber, Carlson, \& Cicchetti, 1991; Wilson \& Gotmman, 1995); intergenerational transmission of abuse (França, Rodrigues, \& Mendes, 2008; Matos, 2002; Pears \& Capaldi, 2001; Renner \& Slack, 2006; Steele \& Pollock, 1974; Strecht, 1998); or the relations between the overall parents and children's characteristics, and the situation they live in (Azevedo \& Maia, 2006; Cichetti, Maughan, \& Toth, 2000; Rogosh et al., 1995)

According to the theory of the intergenerational transmission of abuse, neglect and/or abuse during childhood are good predictors of parents' abusive behaviors towards their own children (Renner \& Slack, 2006; Sneddon et al., 2010). Several studies have shown that the majority of adult offenders were abused in their childhood, also parents who are more strict, inflexible, and negligent, were subjected to similar education styles when growing up (e.g. Haz, Castillo, \& Aracena, 2002; Pears \& Capaldi, 2001; Renner \& Slack, 2006; Steele \& Pollock, 1974). Some studies have actually reported that the rate of intergenerational transmission of abuse is approximately six times greater than the rate of interfamily violence in the general population, occurring in $25-35 \%$ of abuse cases (Gelles \& Loseke, 1993; Kaufman $\&$ Zigler, 1987). In a recent paper by Sneddon et al. (2010), the authors reported that in the Child Protection Register (in the UK), parents with a history of abuse, during their own childhood, presented about twice the risk of becoming abusive. Moreover, in their study developed with 201 mothers, 35\% reported having experienced one or more types of abuse during their childhood. Of these, $24 \%$ reported emotional abuse, $21 \%$ emotional neglect, $13 \%$ physical abuse, $10 \%$ physical neglect and the same percentage sexual abuse; $60 \%$ reported having been victim of more than one type of abuse. Physical maltreatment was the only type that presented an association with the maternal socio-economic status (Sneddon et al., 2010). Also, several other studies have shown that high-risk subjects for child abuse have a lower empathic capacity, and present higher anxiety and discomfort rates when observing other's discomfort, furthermore, they tend to act in a more aggressive and impulsive manner when faced with what they perceive as misbehavior, not taking into account mitigating information (de Paúl, Pérez-Albéniz, Ormaechea, Vergara, \& de Cádiz, 2006; Pérez-Albéniz \& de Paúl, 2003; PérezAlbéniz \& de Paúl, 2004).

However, to our best knowledge, no studies explored if, in cases of intergenerational transmission of abuse, a transmission of the abuse typologies also occurred, i.e., if, for example, neglected parents would become negligent, and so on. It is our understanding that this would be an important aspect to explore, as it would enable not only a deeper knowledge on this subject, but also a better intervention and prevention of potential cases of intergenerational abuse. Thus, with this study we aimed at assessing if in cases of intergenerational transmission of abuse there was also a transmission of abuse typologies (as actually suggested by Pérez and de Paúl (2003), given that many studies on intergenerationality focus solely on physical abuse), as well as the major characteristics regarding the experience and causes of the abuse, the interpersonal relationships, the perceived identification figure as well as the participant's self-perception as an offender. 


\section{Method}

To perform this research, an exploratory design, using qualitative methods, and a convenience sampling was adopted.

\section{PARTICIPANTS}

Ten child aggressors, from both genders, participated in this study. Of the 10 participants, seven were female and three were male, their mean age was 42.8 years $(S D=6.25)$. All the participants had a low educational level as evaluated from the number of schooling years ( $M=7.2$ years; $S D=2.53$ years $)$ and belonged to a medium-low income social group, having unskilled jobs.

All participants met the inclusion criteria: being the legal responsible of the abused child who was / had been followed-up in a mental health hospital unit; having been maltreated during their childhood; being over 18 years old; presenting no cognitive, behavioral or mental disorder that would affect communication and/or data collection.

\section{INSTRUMENTS}

As data collection instruments a sociodemographic questionnaire and a semi-structured, semi-directive and exploratory interview were developed for this study (see Oliveira \& Pais, 2012). Furthermore, we were given access to clinical files on the participants abused children, solely to assess the type of maltreatment inflicted. Gathered data was analyzed with content analysis (Bardin, 1977; Ghiglione \& Matalon, 1992; Krippendorff, 1980; Weber, 1985).

\section{Procedure}

After a literature review, we decided to develop an exploratory study, given that (to our best knowledge) no other study was developed specifically on this topic. In order to achieve our objective a socio-demographic questionnaire and a 15-question semi-structured, semi-directive and exploratory interview were developed. The questions were developed in order to be fully understood by participants from any social and educational background; also they were non-directive, thus allowing a fluent narrative on the participant's actual experiences of maltreatment (Ghiglione \& Matalon, 1992; Lamb, Orbach, Hershkowitz, Esplin, \& Horowits, 2007). The main topics explored were: family environment; relationships between family members, specifically with the mother and father (or other caregivers); social interaction; daily life activities and care received; parents/ caregivers' aggressiveness and behavior; feelings towards the aggression and aggressor; causes for abuse; self-identification as an abuser (see Oliveira \& Pais, 2012).

\section{DATA COLLECTION PROCEDURES}

The participants were contacted through a hospital and schools, attended by their children, in the Lisbon area. Once they agreed to participate in the study an informed consent form, explaining the study and how the interview would be performed and recorded, was delivered and signed by each participant. Any questions or doubts the participants had, were clarified before the interview; no incentives were given and the participants' anonymity was ensured (Bell, 2004; Ghiglione \& Matalon, 1992).

\section{DATA ANALYSIS}

All the interviews were recorded and transcribed verbatim. They were then analyzed using Bardin's content analysis techniques, which include a pre-analysis phase, where the interviews are read once, after transcription, for the researcher to get familiar with the contents (Bardin, 1977). The pre-analysis is followed by an exploration phase, where the transcriptions are read once more, line by line in order to infer their meanings and thus identify the recording units (r.u.); these r.u. are 
basic categorization units which correspond to specific contents, the text is thus divided into several r.u. which are organized and classified according to their content / meaning (Bardin, 1977).

The coding process is the third phase which consists of the reorganization of the raw data of the transcriptions into categories (r.u. were identified, classified and aggregated according to their contents) (Bardin, 1977). These categories were mutually exclusive, homogeneous, and pertinent for the study, being based on the literature review and these study's objectives. The validity and reliability of the categorization process and the exhaustion of the material were ensured (Bardin, 1977; Pais, 2004). To this end, the first author coded the data twice (in two separate points in time), the third author and two other independent judges helped stabilize the categories and re-coded the same data (Bardin, 1977). There was a high consensus between researchers and judges, and any disagreement in the coding was solved by returning to the transcript interviews (Bardin, 1977).

The final categorization produced an amount of data that was then analyzed and interpreted.

To help with the interpretation of the content analysis data, a Fisher's test was performed in order to assess if there was a relation between the suffered and inflicted types of abuse $(p<.005$ was considered significant).

Furthermore, a principal component analysis, with optimal scaling for nominal data which is also known as Homogeneity Analysis (Homals), was used to explore associations between classes as well as to explore the existence of latent constructs that could act as major determinants in intergenerationality situations. These analysis were performed using SPSS v.20.

\section{RESULTS}

We observed that in 8 cases there was a transmission of at least one type of maltreatment. In 7 cases there was an intergen- erational transmission of Physical Abuse, in 2 of Psychological Abuse and in another two of Neglect. In 4 cases different types of abuse, than those suffered, arose. In 5 cases, several types of abuse were inflicted concomitantly (see Table 1).

The Fisher's exact test result gave a $p=.964$, thus, no significant association was found between the suffered and inflicted abuse typologies.

Furthermore, the content analysis originated a total of 813 registration units (r.u.), divided in 7 pre-categories (21 categories, 10 sub-categories) that provided information about the suffered abuse typologies, the context and abuse experience, the causes of abuse, the impact it had on family and social relationships, the perceived identification figures, and the individual's perception as an abuser (see Table 2).

As can be seen on Table 2, Interpersonal Relationships is the pre-category with the highest r.u. frequency ( $D=424$ r.u.), being followed by the pre-categories How the Interviewee Experienced the Abuse, Elements that Influenced the Occurrence of Abuse and Abuse Typologies $(B=113$ r.u.; $C=107$ r.u.; $A=87$ r.u. respectively). Finally, the pre-categories Inflicted Abuse and Perceived Identification Figure $(\mathrm{E}=30$ r.u.; $\mathrm{F}=14$ r.u. respectively), that present a drastically lower number of r.u.

The same pattern of results was observed in the categories and sub-categories.

Regarding the categories, as in the precategories, a great discrepancy between the r.u. frequencies was found.

The categories Family Environment and Intra-family Relationships were the categories with the highest number of r.u. (D1 $=218$ r.u.; D2 = 151 r.u. respectively). These were followed by the categories concerning Physical Abuse, Feelings towards the Aggressor, Own Misbehavior and Social Behavior, which also presented a high frequency of r.u. (A1 $=58$ r.u.; $\mathrm{B} 1=83$ r.u.; $\mathrm{C} 4=36$ r.u.; D3 $=55$ r.u. respectively). The remaining categories (12 out of 21) presented low r.u. frequencies, as can be seen on Table 2. Of these categories with low r.u. frequencies, we can highlight Sexual Abuse (A1 = 1 r.u.) and Aggressor 
Perceived as Identification Figure $(\mathrm{F} 1=4$ r.u.) for presenting the lowest results.

The 10 sub-categories presented r.u. frequencies that were consistent with the ones previously presented for the pre-categories and categories (see Table 2).

Thus, the highest r.u. frequencies were relative to the description of the Family Environment as positive (D1.1 = 125 r.u.) or negative (D1.2 = 93), followed by Exonerating the Aggressor $(\mathrm{B} 1.4=48)$, Physical Abuse Without Objects (A1.2= 45 r.u. ) and, Regarding Social Behavior, Relationships Outside the Family (D3.1 = 38). The lower r.u. frequencies were relative to negative, positive and neutral Feelings Towards the Aggressor $(\mathrm{B} 1.1=23$ r.u.; B1. $2=15$ r.u. B1.3 = 1 r.u. respectively), to Isolation Behaviors (D3.2 = 17 r.u.), to Physical Abuse with Objects (A1.1 = 13 r.u.).

Moreover, some associations between the major categories were found. Apparently, and solely analyzing the qualitative data, in the cases where there was intergenerational transmission of physical abuse the family environment is mostly characterized as negative. Also, most of the negligent interviewees do not perceive themselves as aggressors. Furthermore, we observed that the cases which presented a higher number of r.u. concerning the exoneration of the perpetrator, were those who also had higher r.u. frequencies regarding their own misbehavior as the main cause for aggressions.

A principal components analysis using optimal scaling for nominal variables was performed to further explore possible associations between the content analysis categories.

The results evidenced that the context in which different types of abuse occur is better explained by a two-dimension model, being that the two factors account for $18.53 \%$ of total inertia (variance) observed (Eigenvalue $>1)$.

Taking into account each variable's loadings (see Table 3 ), the first dimension of this two-dimension model was named Maltreatment and Social Interactions, given that the factors with the highest values were D3.1 -Relationships Outside Family (1.110)-, fol- lowed by A1.2 -Physical Abuse Without Objects (1.097)-, B2 -Feeling Towards the Abuse (1.093)- and D2 -Intra-family Relationships (1.056)-. This dimension explained $11.189 \%$ of the total variance.

The second dimension was named Abuse context, feelings and perceptions considering the factors with the highest loadings were B1.1 -Negative Feelings Towards the Aggressor (1.032)-, followed by G2 -No Self-perception as an Offender (0.939)-, C3 -Aggressor's Life Conditions (0.908)-, and E1 -Only Victim of Aggressions (0.890)-. This dimension explained $7.338 \%$ of the total variance.

Figure 1 illustrates the position of each variable in a two-dimension graphic, allowing a better visualization of their distribution and associations. Based on this figure, we can observe three main association groups. Thus categories A2, A1.2, B2, C2, C5, D2, D3.1 and D3.2 are strongly correlated, according to Diamantopoulos and Schlegelmich's (1997) criteria (strong correlations $>.8$, low correlations $<.4$ ).

Furthermore the categories B1.1, C3, E1, $\mathrm{F} 2$ and $\mathrm{G} 2$ also presented strong correlations. However, the categories A4, B1.4, C1, C2, D1.1, D1.2 and E2 presented moderate and low correlations, being the exception the association between the categories D1.1 and B1.4 which was also strong (.872).

Finally, negative strong correlations were found between the categories A1.1 and B1.1 $(-.907)$, and between the categories A1.1 and F2 (-1.0).

\section{Discussion}

Regarding the main research question posed, we observed that in 8 , out of 10 , cases there was a transmission of at least one type of maltreatment. In two cases in which the interviewee has been victim of negligence an intergenerational transmission of negligence occurred, in the remaining cases it arose as a different type of maltreatment than those suffered. Also, in six cases there was transmission of physical abuse. Despite this, there was no statistically significant association 
between the types of abuse suffered and those inflicted $(p>05)$. These results can be justified by the fact that, although there was a transmission of maltreatment in 8 cases, only one type of maltreatment was transmitted in most cases, being that new types of abuse were inflicted, leading to a non-significant statistical relation between both. Thus, we were not able to determine, as suggested by Pérez and de Paúl (2003), a positive association between the types of abuse suffered and inflicted. Furthermore, a significant association between suffering and inflicting specifically physical abuse, as reported in previous studies (e.g. Pérez \& de Paúl, 2003), was not found in our study. Nevertheless, we must reinforce the small number of participants, and highlight that these results are not generalizable.

In our sample the most common types of maltreatment were physical and psychological abuse, and negligence, which goes in the same direction of what is reported by the literature (e.g. Sneddon et al., 2010). However, contrary to what was expected, only one case of sexual abuse was reported; this may be due to the way the question was made, which lead to avoidance of this theme or to indirect answers (e.g. "No, no...hurting me (...) hurting how?").

At this point it is important to refer that the participants, in general, answered more easily to questions about the family or the family environment than to those regarding the abuse suffered or the identification figure, which lead to a great discrepancy in the number of recording units between certain categories (e.g. between the pre-categories D and F). We believe this discrepancy can be explained by the difficulty certain respondents had in accessing and reporting more painful events, remitting to easier and less emotional topics.

Regarding the etiology, the respondents mentioned several aspects, as for example, drug / alcohol consumption, the aggressor's past, living conditions, own misbehavior, or unknown reasons, being these last two the most commonly reported, which does not confirms what has been reported in the literature (Azevedo \& Maia, 2006; Browne,
1998; Eckert et al., 2007; Finkelhor \& DziubaLeatherman, 1994; Holden \& Ritchie, 1991; Margolin \& John, 1997; Rogosh et al., 1995; Sherrod et al., 1984; Sidebotham \& Heron, 2006; Trickett et al., 1991; Wilson \& Gotmman, 1995). Concerning a child's own behavior as cause for abuse, we found that, in this study, the respondents assumed to be guilty, which may be due to an attempt of exonerating the offender, or to accusations heard during their childhood (e.g. "No, we would misbehave, we were children almost like animals").

We looked for commonalities between the various cases and observed, based on the qualitative analysis, that, in cases where there was intergenerational transmission of physical abuse, family environment was characterized mostly as negative. On the other hand, in cases where the respondent is negligent, almost all individuals did not assume themselves as offenders, being there were two exceptions (e.g. "But when I'm not respected I smack them, I don't allow that"; "It's like 'Be good and stay here!' or am I just able to knock something down..."). It was also observed that in cases where there is a large number of r.u. exonerating the aggressor, self-blaming references tend to arise. It was also observed that in some cases where the perpetrator is not recognized as the identification figure, the interviewee assumes himself as an aggressor.

The Principal Component Analysis allowed a more accurate understanding of these possible associations between the variables, suggesting a two-dimension model.

The first dimension, which we named Maltreatment and social interactions, dimension included the following categories: Physical Abuse Without Objects; Psychological Abuse; Negligence; Exonerating Aggressor; Feelings Towards Abuse; Aggressor's Past; Own Misbehavior; No Apparent Reason; Positive Family Environment; Relationships Outside the Family; Isolation; and Intra-family Relationships.

The second dimension, Abuse Context, Feelings and Perceptions, included the categories: Physical Abuse with Objects; Negative Feelings towards Aggressor; Neutral 
Feelings towards Aggressor; Toxic Habits and Consumptions; Aggressor's Life Conditions; Negative Family Environment; Only Victim of Aggressions; Aggressions on Self and Others; Identification Figure - other; and No Self-perception as Aggressor.

Based on this two-dimension model, we can observe that the occurrence of physical abuse (without objects) (e.g. "because he would hit us a lot, now and then he would beat us") and psychological abuse (e.g. "sometimes she would use that [threatening that the father would beat them] to make us do things, do those things...she used the threat of suffering, more than it would really hurt") were strongly associated with each other and with toxic habits / consumptions (of mostly alcohol; e.g. "My dad would come, and sometimes he had one too many drinks") or no apparent reasons as main causes of abuse. Also, in these cases the interviewees spoke more of the feelings towards the abuse. References to social behavior and intra-family relationships were also common.

Furthermore, negligence (e.g. "I only went to live with her [mother] when I was 13 years old") appeared to be moderately associated with exonerating the perpetrator (e.g. "but today I can understand what he did to us"), and the abuse justified as a consequence of the aggressor's past (e.g. "People that were used to working since children, it is obvious that reflected on his children, right?"). In these cases the family environment is mostly characterized as positive.

Moreover, when the interviewee was the only victim of abuse (e.g. "Anything that happened it would be me, I got always beat up"), the perceived identification figure tended to be someone other than the aggressor, being that these individuals do not perceive themselves as current aggressors (e.g. "Nervous, not aggressive... I scream a lot, but before I hit someone I really have to be very angry, but I scream...Very, very nervous" [Physical offender]). However, in these cases, the individual's revealed both positive and negative feelings towards the aggressor, and the abuse is justified by their life conditions (e.g. "all life's situations").

Also, negative correlations were found between three categories, thus, when physical abuse (with objects) occurs, there are no negative feelings towards the aggressor, however, and despite this lack of negative feelings, the perceived identification figure is not the aggressor.

Finally, this study presents limitations, specifically the use of a small and very specific sample, gathered through a public health service, which may limit the characteristics of the sample. When gathering this sample we were faced with adherence issues, i.e., approximately 40 individuals' were initially contacted in order to participate in this study, of those only 10 actually participated, which leads to a sample mortality rate of around $75 \%$, which is much higher than that reported in other studies with child abusers (e.g. Pechorro, Poiares, \& Vieira, 2008). Furthermore, we were only able to assess one case of sexual abuse, in a mostly female sample, thus, and given that child sexual abuse is still a highly reported type of abuse, we believe that lack of incidence in this sample may be due to the way the question aimed assessing it was elaborated. A final limitation of this interview protocol is that it does not ascertain the consequences of abuse for the respondents, however, that was not the aim of this study.

However, we believe it brings new information, and that it is useful as a pre-study for the use of this interview in a sample of abusive parents. We propose that this instrument is validated in a wider sample and applied as a screening instrument in primary intervention and prevention programs with potential aggressors (Oliveira \& Pais, 2012). Also, we believe that our findings should be further explored, aiming specifically at filling the knowledge gap that exists regarding the intergenerational transmission of abuse typologies, either than physical abuse. 
TABLE 1

INTERGENERATIONAL TRANSMISSION OF ABUSE TYPOLOGIES

\begin{tabular}{|c|c|c|}
\hline \multirow{2}{*}{ Cases } & \multicolumn{2}{|c|}{ Maltreatment typologies } \\
\hline & Suffered & Inflicted \\
\hline E1 & $\begin{array}{l}\text { Physical with (belt) and without objects; psychol- } \\
\text { ogical abuse; neglect }\end{array}$ & Physical without objects \\
\hline E2 & Physical without objects; neglect & Physical without objects \\
\hline E3 & Physical without objects; psychological abuse & Psychological neglect; psychological abuse \\
\hline E4 & Physical with (belt) and without objects & Psychological neglect \\
\hline E5 & Physical without objects; neglect & Psychological neglect \\
\hline E6 & $\begin{array}{l}\text { Physical with (belt) and without objects; psychol- } \\
\text { ogical abuse; neglect }\end{array}$ & Physical without objects \\
\hline E7 & $\begin{array}{l}\text { Physical with (belt) and without objects; psychol- } \\
\text { ogical abuse }\end{array}$ & $\begin{array}{l}\text { Physical without objects; } \\
\text { psychological abuse }\end{array}$ \\
\hline E8 & Physical with (belt) and without objects & $\begin{array}{l}\text { Physical with objects (baseball bats, nails, } \\
\text { knifes); psychological abuse; psychological and } \\
\text { physical neglect }\end{array}$ \\
\hline E9 & $\begin{array}{l}\text { Physical with (belt) and without objects; sexual } \\
\text { abuse }\end{array}$ & $\begin{array}{l}\text { Physical without objects; } \\
\text { psychological abuse; psychological neglect }\end{array}$ \\
\hline E10 & Physical without objects; neglect & $\begin{array}{l}\text { Physical without objects; } \\
\text { psychological neglect }\end{array}$ \\
\hline
\end{tabular}


TABLE 2

CONTENT ANALYSIS' PRE-CATEGORIES, CATEGORIES AND SUB-CATEGORIES

\begin{tabular}{|c|c|c|c|}
\hline Pre-categories & Categories & Sub-categories & $\begin{array}{l}\text { r.u. } \\
\text { frequency }\end{array}$ \\
\hline $\begin{array}{l}\text { A (Abuse ty- } \\
\text { pologies) }\end{array}$ & $\begin{array}{l}\text { A1 (Physical Abuse) } \\
\text { A2 (Psychological Abuse) } \\
\text { A3 (Negligence) } \\
\text { A4 (Sexual Abuse) }\end{array}$ & $\begin{array}{l}\text { A1.1 (With objects) } \\
\text { A1.2 (Without Objects) }\end{array}$ & $\begin{array}{c}13 \\
45 \\
14 \\
14 \\
1\end{array}$ \\
\hline $\begin{array}{l}\mathrm{B} \text { (How the in- } \\
\text { terviewer expe- } \\
\text { rienced the } \\
\text { abuse) }\end{array}$ & $\begin{array}{l}\text { B1 (Feeling towards the aggressor) } \\
\text { B2 (Feeling towards the abuse) }\end{array}$ & $\begin{array}{l}\text { B1.1 (Negative) } \\
\text { B1.2 (Positive) } \\
\text { B1.3 (Neutral) } \\
\text { B1.4 (Exonerating the perpetrator) }\end{array}$ & $\begin{array}{c}23 \\
15 \\
1 \\
48 \\
26\end{array}$ \\
\hline $\begin{array}{l}\text { C (Elements } \\
\text { that influenced } \\
\text { the occurrence } \\
\text { of abuse) }\end{array}$ & $\begin{array}{l}\text { C1 (Toxic habits and consumptions) } \\
\text { C2 (Aggressor's past) } \\
\text { C3 (Aggressor's life conditions) } \\
\text { C4 (Own misbehavior) } \\
\text { C5 (No apparent reason) }\end{array}$ & & $\begin{array}{l}15 \\
13 \\
20 \\
36 \\
23\end{array}$ \\
\hline $\begin{array}{l}\mathrm{D} \text { (Interpersonal } \\
\text { relationships) }\end{array}$ & $\begin{array}{l}\text { D1 (Family environment) } \\
\text { D2 (Intra-family relationships) } \\
\text { D3 (Social Behavior) }\end{array}$ & $\begin{array}{l}\text { D1.1 (Positive) } \\
\text { D1.2 (Negative) } \\
\text { D3.1 (Relationships outside family) } \\
\text { D3.2 (Isolation) }\end{array}$ & $\begin{array}{c}125 \\
93 \\
151 \\
38 \\
17\end{array}$ \\
\hline $\begin{array}{l}E \text { (Inflicted } \\
\text { abuse) }\end{array}$ & $\begin{array}{l}\text { E1 (Only victim of aggressions) } \\
\text { E2 (Aggressions on self and others) }\end{array}$ & & $\begin{array}{l}10 \\
20\end{array}$ \\
\hline $\begin{array}{l}\text { F (Perceived } \\
\text { identification } \\
\text { figure) }\end{array}$ & $\begin{array}{l}\text { F1 (Offender perceived as identifica- } \\
\text { tion figure) } \\
\text { F2 (Another perceived identification } \\
\text { figure) }\end{array}$ & & $\begin{array}{l}4 \\
10\end{array}$ \\
\hline $\begin{array}{l}\text { G (Self-percep- } \\
\text { tion as an of- } \\
\text { fender) }\end{array}$ & $\begin{array}{l}\text { G1 (Self-perception as an offender) } \\
\text { G2 (No self-perception as an offen- } \\
\text { der) }\end{array}$ & & $\begin{array}{l}23 \\
15\end{array}$ \\
\hline Total & & & 813 \\
\hline
\end{tabular}


TABLE 3

PRINCIPAL COMPONENT ANALYSIS' COMPONENT LOADINGS

\begin{tabular}{|l|cc|}
\hline Variables (Categories) & \multicolumn{2}{|c|}{$\begin{array}{c}\text { Dimensions } \\
\text { 2.- Abuse context, feelings } \\
\text { and perceptions }\end{array}$} \\
\hline Physical abuse with objects & $\begin{array}{c}\text { 1.- Maltreatment and social } \\
\text { interactions }\end{array}$ & -.822 \\
Physical abuse without objects & .260 & -.107 \\
Psychological abuse & 1.097 & -.267 \\
Negligence & 1.037 & .364 \\
Negative feelings towards aggressor & .717 & 1.032 \\
Neutral feelings towards aggressor & -.037 & .709 \\
Exonerating aggressor & .207 & .241 \\
Feelings towards abuse & .547 & -.165 \\
Toxic habits and consumptions & 1.093 & .497 \\
Aggressor's past & .290 & -.278 \\
Aggressor's life conditions & 1.004 & .908 \\
Own misbehavior & -.056 & -.009 \\
No apparent reason & .256 & -.255 \\
Negative family environment & 1.042 & .611 \\
Positive family environment & .606 & .510 \\
Intra-family relationships & .644 & .067 \\
Relationships outside the family & 1.056 & -.057 \\
Isolation & 1.110 & -.282 \\
Only victim of aggressions & 1.041 & .890 \\
Aggressions on self and others & .053 & .675 \\
Identification figure - other & .502 & .855 \\
No self-perception as aggressor & -.232 & .939 \\
\hline
\end{tabular}




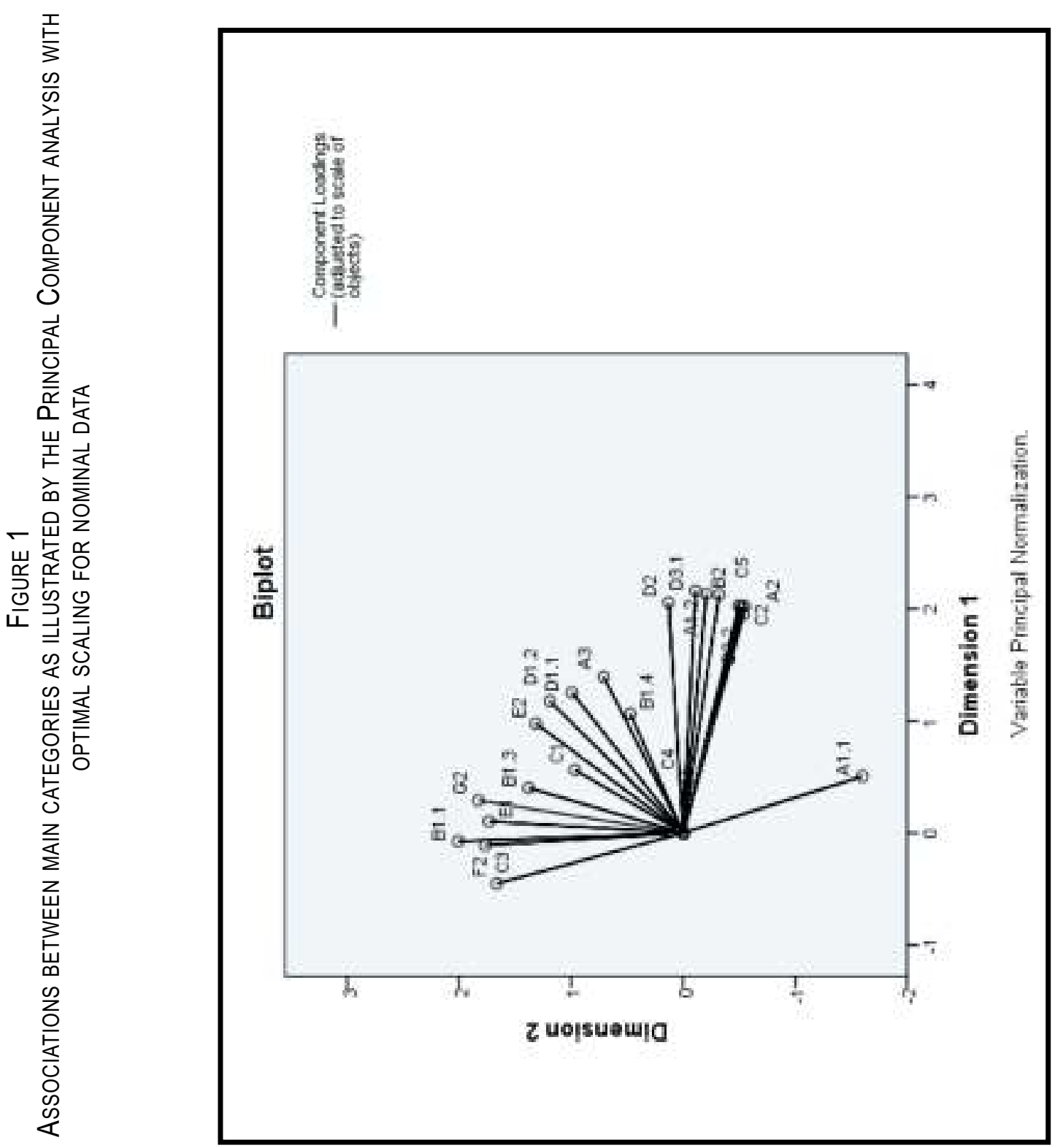




\section{REFERENCES}

Azevedo, M., \& Maia, A. (2006). Maus-tratos à criança [Child abuse]. Lisboa: Climepsi Editores.

Bardin, L. (1977). Análise de conteúdo [Content analysis]. Lisboa: Edições 70.

Bell, J. (2004). Planear e conduzir entrevistas. In J. Bell (Ed.), Como realizar um projecto de investigação: Um guia para a pesquisa em ciências sociais e da educação [How to conduct a research project: A guide for research in social sciences and education] (pp. 137-149). Lisboa: Gradiva.

Browne, K. (1998). The nature of child abuse and neglect: An overview. In K. Browne, C. Davies, \& P. Stratton (Eds.), Early prediction and prevention of child abuse (pp. 15-27). London: Wiley.

Chadwick, D. (1999). The message. Child Abuse \& Neglect, 23(10), 957-961. doi: 10.1016/S0 145-2134(99)00072-1.

Cicchetti, D., Maughan, A., \& Toth, S. (2000). An ecological-transactional model of child maltreatment. In A. Sameroff, M. Lewis, \& S. Miller (Eds.), Handbook of developmental psychology (pp. 693-722). New York: Plenum.

de Paúl, J., Pérez-Albéniz, A., Ormaechea, A., Vergara, A., \& de Cádiz, B.T. (2006). Aggression inhibition in high- and low-risk subjects for child physical abuse: Effects of a child's hostile intent and the presence of mitigating information. Aggressive Behavior, 32, 216-230. doi: 10.1002/ab.20123.

Diamantopoulos, A., \& Schlegelmilch, B. (1997). Taking the fear out of data analysis. London: Thomson Learning.

Eckert, E., Ribeiro, E., Silva, A., \& Souza, A. (2007). Castigo físico adotado por pais acompanhantes no disciplinamento de crianças e adolescentes [Physical punishment adopted by parents in disciplining of children and adolescents]. Acta Paulista Enfermagem, 20(3), 377-383. doi: http://dx.DOI.org/10.1590/S010 321002007000300006.

Erickson, M. \& Egeland, B. (2002). Child neglect. In J. Myers, L. Berliner, J. Briere, C. Hendrix, C. Jenny, \& T. Reid (Eds.), The APSAC handbook: Child maltreatment (pp. 3-16). CA: Sage. Finkelhor, D., \& Dziuba-Leatherman, J. (1994). Victimization of children. American Psychologist, 49(3), 173-183. doi: 10.1037/0003066 X. 49.3.173.

França, C., Rodrigues, D., \& Mendes, A. (2008). A violência do abuso sexual infantil: Interfaces da compulsão à repetição e da identificação com o agressor [The violence of child sexual abuse: Interface of the repetition compulsion and identification with the agressor]. Proceedings of the III Congresso Internacional de Psicopatologia Fundamental / IX Congresso Brasileiro de Psicopatologia Fundamental (pp. 1-7). São Paulo: Associação Universitária de Pesquisa em Psicopatologia Fundamental.

Gelles, R., \& Loseke, D. (1993). Issues in causes. In R. Gelles, \& D. Loseke (Eds.), Current controversies on family violence (pp. 209-221). California: Sage.

Ghiglione, R., \& Matalon, B. (1992). Como inquirir? As entrevistas [How to inquire? The interviews]. In R. Ghiglione \& B. Matalon (Eds.), O inquérito: Teoria e prática (pp. 63104). Oeiras: Celta Editora.

Grilo, M. (2004). Criança vítima de maus-tratos Que protecção? Um longo caminho até ao reconhecimento do direito aos direitos [Victim of child abuse - What protection? A long way towards the recognition of the right to rights]. 
Unpublished Masters thesis. Instituto Superior de Psicologia Aplicada (ISPA), Lisbon.

Haz, A.M., Castillo, R., \& Aracena, M. (2002). Adaptación preliminar del instrumento Multidimensional Trauma Recovery and Resilience (MTRR) en una muestra de madres maltratadoras físicas con historia de maltrato físico y madres no maltratadoras con historia de maltrato físico [Preliminary adaptation of the instrument Multi dimensional Trauma Recovery and Resilience (MTRR) in a sample of physical abusive mothers with a history of physical abuse and non-abusive mothers with a history of physical abuse]. Child Abuse \& Neglect, 27, 807-820. doi: 10.1016/S014521 34(03)0 0118-2.

Holden, G., \& Ritchie, K. (1991). Linking extreme marital discord, child rearing, and child behavior problems: Evidence from battered women. Child Development, 62(2), 311-327. doi: 10.11 11/j.1467-8624.19 91.tb01533.x.

Kaufman, J., \& Zigler, E. (1987). Do abused children become abusive parents? American Journal of Ortopsychiatry, 57(2), 186-192. doi: 10.1111/j.1939-0025.1987.tb035 28.x.

Kelly, L. \& Pringle, K. (2009). Gender and child harm. Child Abuse Review, 18, 367-371. doi: 10.1002/car.1097.

Krippendorff, L. (1980). Content analysis: An introduction to its methodology. California: Sage.

Lamb, M., Orbahc, Y., Hershkowitz, I., Esplin, P., \& Horowitz, D. (2007). A structural forensic interview protocol improves the quality of informativeness of investigative interviews with children: A review of research using the NIC HD Investigative Interview Protocol. Child Abuse and Neglect, 31(11-12), 1201-1231. doi: http://dxOI.org/10.1016/j.chiabu.2007.03. 021 .
Margolin, G., \& John, R. (1997). Children's exposure to marital aggression: Direct and mediated effects. In G. Kantor \& J. Jasinki (Eds.), Out of the darkness: Contemporary perspectives on family violence (pp. 90-104). Thousand Oaks, CA: Sage.

Matos, A.C. (2002). Psicanálise e psico-terapia psicanalítica [Psychoanalysis and psychoanalytic psychotherapy]. Lisboa: Climepsi.

Morais, E. (2001). Maus-tratos fisicos de crianças [Physical abuse of children]. Unpublished Masters dissertation. Instituto Superior de Psicologia Aplicada, Lisboa.

Oliveira, R.V., \& Pais, L.G. (2012). Uma proposta de prevenção nos maus-tratos à criança: estudo exploratório [A proposal for the prevention of child maltreatment: An exploratory study]. Proceedings of the $9^{\circ}$ Congresso Nacional de Psicologia da Saúde (pp. 1020-1026). Lisboa: Placebo.

Oliveira-Formosinho, J. \& Araújo, S. (2002). Entre o risco biológico e o risco social: Um estudo de caso [Between the biological risk and social risk: A case study]. Educação e Pesquisa, 28(2), 87-103. doi: http://dx.DOI.org/ 10.1590S1517-97022002000200007.

Pais, L.G. (2004). Uma história das ligações entre a psicologia e o direito em Portugal: Perícias psiquiátricas médico-legais e perícias sobre a personalidade como analisadores [A history of the connections between psychology and law in Portugal: Forensic psychiatric expert reports and reports concerning their personality as analyzer]. Unpublished Doctoral Dissertation. Universidade do Porto, Porto.

Palacios, J., Jiménez, J., Oliva, A., \& Saldaña, D. (1998). Malos tratos a los niños en la familia [Maltreatment of children in the family]. In M. Rodrigo, \& J. Palacios (Eds.), Familia e desa- 
rrollo humano (pp. 399-421). Madrid: Alianza Editorial.

Palacios, J., Moreno, M., \& Jiménez, J. (1995). El maltrato infantil: Concepto, tipos, etiología [Child abuse: Concept, types, etiology.]. Infancia y Aprendizaje, 71, 7-21. Retreived in August 2010 from http://dial net.unirioja.es/ servlet/articulo? codigo $=48506$.

Pears, K., \& Capaldi, D. (2001). Intergenerational transmission of abuse: A two generational prospective study of an at-risk sample. Child Abuse \& Neglect, 25, 1439-1461. doi: http:// dx.DOI. org/10.1016/S0145-2134(01)0028 61.

Pechorro, P.S., Poiares, C., \& Vieira, R.X. (2008). Caracterização psicológica de uma amostra forense de abusadores sexuais. Análise Psicológica, 4(26), 615-623. Retrieved in 2010 from http://www.scielo.gpeari.mctes.pt/scielo.php?s cript=sci_artt ext\& pid=S0870-82312008000 400007\&lng=pt\&nr $\mathrm{m}=$ iso.

Pérez-Albéniz, A., \& de Paúl, J. (2003). Dispositional empathy in high- and low-risk parents for child physical abuse. Child Abuse \& Neglect, 27, 769-780. doi: 10.10 16/S0145-2134 (03)00111-X.

Pérez, E.G., \& de Paúl, J. (2003). La transmisión intergeneracional del maltrato físico infantil: Estudio en dos generaciones [The intergenerational transmission of child physical abuse: A study in two generations]. Psicothema, 15(3), 452-457. Retrieved in 2010 from http://www. uv.es/seo ane/boletin/previos/N102-3.pdf.

Pérez-Albéniz, A., \& de Paúl, J. (2004). Gender differences in empathy in parents at high- and low-risk of child physical abuse. Child Abuse \& Neglect, 28, 289-300. doi: 10.1016/j.chia bu.2003.11.017.

Renner, L., \& Slack, K. (2006). Intimate partner violence and child maltreatment: Understand- ing intra- and intergenerational connections. Child Abuse \& Neglect, 30(6), 599-617. doi: http://dx.DOI.org/10.1016/j.chiabu.2005.12. 005.

Rogosh, F., Cicchetti, D., Shields, A., \& Toth, S. (1995). Parenting dysfunction in child maltreatment. In M. Bornstein (Eds.), Handbook of parenting: Applied and practical parenting (Vol. 4). Mahwah, NJ: Erlbaum.

Runyan, D., Wattam, C., Ikeda, R., Hassan, F., \& Ramiro, L. (2002). Child abuse and neglect by parents and other caregivers. In E.G. Krug, L.L. Dahlberg, J.A. Mercy, A.B. Zwi, \& R. Lozano (Eds.), The world report on violence and health (pp. 59-86). Geneva: World Health Organization.

Sherrod, K., O'Connor, S., Vietze, P., \& Altemeier, W. (1984). Child health and maltreatment. Child Development, 55, 1174-1183. Retrieved in September 2010 from http://www.jstor. org/stable/1129986.

Sidebotham, P., \& Heron, J. (2006). Child maltreatment in the "children of the nineties": A cohort study of risk factors. Child Abuse \& Neglect, 30(5), 497-522. doi: http://dx.DOI. org/10.1016/j.chiabu. 2005.11.005.

Sneddon, H., Iwaniec, D., \& Stewart, M. (2010). Prevalence of childhood abuse in mothers taking part in a study of parenting their own children. Child Abuse Review, 19(1), 39-55. doi: 10.1002/car.1078.

Steele, B.J., \& Pollock, C.B. (1974). A psychiatric study of parents who abuse infants and small children. In R.E. Helfer, \& C.H. Kempe (Eds.), The battered child (pp. 89-133). Chicago: University of Chicago.

Statistics Unit of APAV (2010). Estatísticas APAV: Crianças vitimas de crime 2000-2009 [APAV Statistics: Children victims of crime 2000- 
2009]. Retrieved in August 2010 from http:// www.apav.pt/.

Strecht, P. (1998). Crescer vazio: Repercussões psíquicas do abandono, negligência e maustratos em crianças e adolescentes [Growing up empty: psychological implications of abandonment, neglect and maltreatment in children and adolescents]. Lisboa: Assírio e Alvim.

Trickett, P., Aber, J., Carlson, V., \& Cicchetti, D. (1991). Relationship of socioeconomic status to the etiology and developmental sequelae of physical child abuse. Developmental Psychology, 27(1), 148-158. doi: 10.1037/0012-16 49. 27.1.148.
United Nations (2006). Rights of the child: Report of the independent expert for the United Nations study on violence against children. Retrieved in September 2010 from http://www.who.int/me dicines/areas/human_rights/en/.

Weber, R. (1985). Basic content analysis. Berverly Hills: Sage.

Wilson, B., \& Gottman, J. (1995). Parenting dysfunction in child maltreatment. In M. Bornstein (Eds.), Handbook of parenting: Applied and practical parenting (Vol. 4). Mahwah, NJ: Lawrence Erlbaum Associates.

Instituto Universitário (ISPA)

Lisbon

Portugal

Reception: February 15, 2012 Accepted: October 9, 2012 
